Cordova Jurnal

ISSN (P) 2302-3155,

(e) 2714-5808

Vol. 9, No. 12019

\title{
STUDI KOMPARATIF MAKNA KONOTASI WARNA DALAM \\ BUDAYA MASYARAKAT BARAT DAN \\ MASYARAKAT SUKU SASAK LOMBOK INDONESIA
}

\author{
Ika Rama Suhandra \\ UIN Mataram, Indonesia \\ ikaramasuhandra@uinmataram.ac.id
}

\begin{abstract}
Abstrak
Artikel ini menginvestigasi perbedaan konotasi istilah warna dalam masyarakat barat (pengguna Bahasa Inggris) dan Masyarakat Suku Sasak Lombok Indonesia dengan perhatian khusus pada penggunaan figuratif warna hitam, putih, abu-abu, coklat, kuning, merah, hijau, biru dan beberapa warna lainnya. Konotasinya dinilai berdasarkan apakah frasa-frasa di mana istilah warna terjadi biasanya ortofemistik, eufemisme, atau disfemistik. Berdasarkan analisis dan pembahasannya, dapat disimpulkan beberapa hal; bahwa secara kuantitas, pemaknaan secara orthopemis, eufimis, serta disfemis masyarakat barat lebih kaya dibandingkan dengan pemaknaan yang ada pada masyarakat suku Sasak. Dalam masyarakat barat, pemaknaan orthophemik lebih sering terjadi, sementara pemaknaan secara eufimis dan disfemis, sering juga terjadi walaupun intensitasnya tidak sama seperti dalam orthophonemik, dan ini merata kita temukan dalam semua warna di masyarakat barat apakah untuk warna primer maupun warna sekunder. Sementara itu, dalam masyarakat suku Sasak makna orthopemik, eufimis, dan disfemis hanya dapat ditemukan pada warna primer. Sementara warna sekunder (warna yang berasal dari percampuran warna lain), hampir jarang ditemukan pemaknaan konotasi yang bersifat eufimis, dan disfemis. Kalaupun ada, itupun dikarenakan karena masyarakat mengambil atau meminjam istilah atau frase itu dari bahasa lain. Kekayaan pemaknaan konotatif warna pada masyarakat disebabkan karena proses semiosisnya dipengaruhi oleh cara pandang, kekayaan budaya, kekayaan pengalaman, kejadian yang beragam yang terjadi pada masyarakat barat berbeda dengan apa yang terjadi dengan masyarakat suku Sasak.
\end{abstract}


Cordova Jurnal

ISSN (P) 2302-3155,

(e) 2714-5808

Vol. 9, No. 12019
Jurnal kajian Bahasa dan Budaya terbit 2 kali setahun oleh UPT. Pusat Pengembangan

Bahasa (P2B) UIN Mataram. Tersedia online pada

https://journal.uinmataram.ac.id/index.php/cordova

Kata Kunci: Warna, Konotasi, Disfemisme, Eufemisme, Orrthophemism, X-phemism.

\section{PENGANTAR}

Masyarakat dalam kehidupannya sering kali memiliki pemaknaan terhadap segala realita dan fakta, baik itu fakta sosial, budaya, politik, agama, ekonomi dan lain sebagainya. Pemaknaan tidak hanya dilakukan atas sesuatu yang bersifat makro (topik-topik mainstream), tetapi juga pemaknaan itu dilakukan pada sesuatu yang bersifat mikro misalnya; pemaknaan arti warna. Warna dalam tataran denotatif dipersepsikan sama hampir diseluruh dunia, tapi pada tataran konotatif, ia kadang kala dipersepsikan berbeda bahkan sangat jauh berbeda antara masyarakat yang satu dengan masyarakat yang lain.

Dalam masyarakat Barat dan Asia, warna hitam misalnya diasosiasikan, sebagai warna yang membawa pesan kesuraman, kegelapan, kemiskinan, bahkan ketidak berdayaan. Pada titik ini, warna hitam dipersepsikan sama, antara masyarakat barat dan Asia, bahkan secara luas pemaknaan itu sudah bersifat universal. Namun, pada tataran pemaknaan dalam praktik sosial dan budaya. Pemaknaannya disesuaikan dengan kultur sosial dimana warna itu diinterpretasikan. Sebagai contoh pada masyarakat barat, ketika mereka mendengar frase 'Black September', maka yang ada di pikiran dan benak mereka adalah tentang suatu kejadian suram dan menakutkan yang terjadi di bulan September. Bisa saja kejadian tersebut berkaitan dengan pembantaian, pembunuhan masal, pengusiran masal, dan lain sebagainya. Sementara 
Cordova Jurnal

ISSN (P) 2302-3155,

(e) 2714-5808

Vol. 9, No. 12019
Jurnal kajian Bahasa dan Budaya terbit 2 kali setahun oleh UPT. Pusat Pengembangan

Bahasa (P2B) UIN Mataram. Tersedia online pada

https://journal.uinmataram.ac.id/index.php/cordova

itu, di Indonesia tidak ada penggunaan frase 'September Hitam', masyarakat Indonesia cenderung menggunakan warna 'kelam' atau 'kelabu' untuk mengungkapkan situasi-situasi tersebut. Masyarakat Indonesia kemudian akan mengatakan 'September Kelam' atau 'September kelabu'. Kedua frasa tersebut di Indonesia identik dengan peristiwa pembantaian Dewan Jendral yang dilakukan oleh Partai Komunis Indonesia yang berlangsung pada tanggal 30 September tahun 1965, atau yang lebih populer disebut dengan G30S/PKI.

Dalam tataran praktik sosial-budaya, contohnya dalam ritual perkawinan, masyarakat barat cenderung menggunakan 'White Gown' atau gaun putih ketika prosesi pesta perkawinan dilakukan. Berbeda dengan dimasyarakat suku Sasak di Lombok, dan atau Suku Kajang di Sulawesi Selatan Indonesia, pada saat ritual perkawinan, atau gawai adat dilakukan, masyarakat pada kedua daerah ini menggunakan warna hitam sebagai baju adat dalam pelaksanaan ritual perkawinannya.

Berangkat dari fakta di atas, maka artikel ini menjelaskan panjang lebar tentang persamaan dan perbedaan konotasi istilah warna dalam budaya masyarakat Barat dan budaya masyarakat Indonesia khususnya suku Sasak dengan perhatian khusus pada penggunaan figuratif warna hitam, putih, abu-abu, coklat, kuning, merah, hijau, biru dan beberapa warna lainnya. Pemaknaan konotasinya mengacu pada istilah yang diperkenalkan oleh Allan dan Burridge (2006) yakni 'X-phemisme'. Yang dimaksud dengan 'X-phemismse' di sini adalah istilah frase yang digunakan dalam beragam bentuk tuturan atau suasana tertentu, misalnya orthophemism (bicara langsung apa adanya), dysphemisms 
Cordova Jurnal

ISSN (P) 2302-3155,

(e) 2714-5808

Vol. 9, No. 12019
Jurnal kajian Bahasa dan Budaya terbit 2 kali setahun oleh UPT. Pusat Pengembangan

Bahasa (P2B) UIN Mataram. Tersedia online pada

https://journal.uinmataram.ac.id/index.php/cordova

(bahasa kasar), dan eufemisme (bicara yang diperhalus). Orthophemisms dan eufemisme adalah kata atau frasa yang digunakan sebagai alternatif untuk ekspresi yang tidak disukai. Sementara itu, ortofemisme biasanya lebih formal dan lebih langsung (atau literal) daripada eufemisme. Eufemisme biasanya lebih bersifat sehari-hari dan figuratif (atau tidak langsung) daripada ortofemisme. Disfemisme adalah kata atau frasa dengan konotasi yang menyinggung baik tentang denotatum dan atau kepada orang yang dialamatkan atau mendengar ucapan itu.

\section{LANDASAN TEORI}

Semiotika, sebagai disiplin yang mendasari semua sistem kognitif biologis manusia dan non manusia meliputi dan menyediakan kerangka epistemologis yang memadai untuk semua perspektif lainnya. Menurut Konsepsi Charles S. Peirce, tanda adalah sesuatu yang mewakili sesuatu yang lain dan yang dipahami atau memiliki makna bagi seseorang. Tanda digunakan sebagai pengganti hal lain dalam menyampaikan konsep tentang hal itu. Tanda berfungsi merepresentasikan atau mengganti sesuatu, yang mungkin tidak ada, untuk beberapa sistem yang mampu menafsirkan substitusi seperti itu. Peirce menyebut tiga kategori penandaan yakni representamen, objek, dan interpretan. Representamen adalah tanda substitusi, objek adalah benda substitusi, dan interpretan adalah gagasan yang representamen transmisikan tentang benda itu. Selanjutnya, Pierce mengatakan bahwa tanda tidak 
Cordova Jurnal

ISSN (P) 2302-3155,

(e) 2714-5808

Vol. 9, No. 12019
Jurnal kajian Bahasa dan Budaya terbit 2 kali setahun oleh UPT. Pusat Pengembangan

Bahasa (P2B) UIN Mataram. Tersedia online pada

https://journal.uinmataram.ac.id/index.php/cordova

menggantikan objek dalam totalitasnya, hanya mencakup beberapa aspek.

Sementara itu, Roland Barthes, melihat tanda dibangun melalui dua level pemaknaan, yaitu denotasi dan konotasi. Hasyim, (2014: 39), menjelaskan pemaknaan tentang denotasi dan konotasi. Denotasi dipandang sebagai sistem signifikasi tahap pertama (sistem primer), yaitu pemaknaan secara umum diterima dalam konvensi dasar sebuah masyarakat. Selanjutnya, konotasi sebagai sistem signifikasi tahap kedua (sistem sekunder), adalah pemaknaan tertentu (makna tambahan) dari sistem primer. Konotasi menghasilkan makna baru yang diberikan oleh masysrakat pengguna tanda yang dapat dilatarbelakangi oleh ideologi, sosial budaya, dan berdasarkan konvensi yang ada dalam masyarakat. Konotasi digunakan pemakai tanda untuk menjelaskan realitas sosial budaya, yang dapat menjadi label sosial yang membudaya dimasyarakat.

Charles Morris, menggunakan konsepsi triadik tentang tanda. Ia mengusulkan tiga tingkat atau dimensi semiosis: (1) dimensi sintaksis, di mana hubungan antara tanda-tanda dipertimbangkan; (2) dimensi semantik, di mana hubungan antara tanda dan benda yang dilambangkan dipelajari; dan (3) dimensi pragmatik, di mana hubungan antara tanda dan penerjemah diperhitungkan.

Sejauh ini, kita berasumsi bahwa warna dapat berfungsi sebagai tanda. Mengambil gagasan tanda lagi, pertanyaannya adalah: apakah warna mampu mewakili sesuatu yang berdiri di luar dirinya sendiri? Dengan kata lain, apakah merah hanya menyiratkan kemerahan atau 
Cordova Jurnal

ISSN (P) 2302-3155,

(e) 2714-5808

Vol. 9, No. 12019
Jurnal kajian Bahasa dan Budaya terbit 2 kali setahun oleh UPT. Pusat Pengembangan

Bahasa (P2B) UIN Mataram. Tersedia online pada

https://journal.uinmataram.ac.id/index.php/cordova

bisa dikaitkan dengan konsep lain? Warna merupakan proses semiotis di masyarakat dan telah menjadi tanda budaya bagi penuturnya. Berbagai konsep warna telah dikaitkan dengan budaya yang merepresentasikan pandangan atau cara berpikir masyarakat (Hasyim, 2015: 727). Berkaitan dengan tanda dan proses semiosis, Caivano (1998, 390-397), yang berlandaskan pada teori warna C. Janello (1998, 483-496) menjelaskan deskripsi tentang teori warna seperti di bawah ini.

\section{Semantik Warna}

Dalam dimensi semantik, di mana tanda-tanda dianggap dalam kapasitas mereka sebagai yang mewakili atau menandakan hal-hal lain, untuk mengirimkan informasi atau konsep yang berada di luar tanda itu sendiri. Kata kunci untuk aspek ini adalah substitusi, yaitu, warna dianggap sebagai tanda yang dapat menggantikan hal-hal lain. Di sini, hubungan antara warna dan apa yang dapat mereka wakili, kode dan asosiasi yang dibentuk melalui warna, dan cara memaknai warna berubah sesuai dengan konteks penampilan dan terkait dengan faktor manusia seperti budaya, usia, dan jenis kelamin.

\section{Pragmatik Warna}

Beberapa aspek dimensi pragmatis warna telah banyak yang diteliti. Dalam hal ini, hubungan yang ada di antara tanda-tanda dan penerjemah atau pengguna merupakan suatu hal yang sangat diperhitungkan. Di antara topik yang dapat memasuki tingkat penyelidikan ini, dapat dipertimbangkan beberapa hal: aturan yang digunakan warna sebagai tanda, fungsi warna dalam lingkungan alam dan budaya, cara organisme mengidentifikasi warna untuk bertahan 
Cordova Jurnal

ISSN (P) 2302-3155,

(e) 2714-5808

Vol. 9, No. 12019
Jurnal kajian Bahasa dan Budaya terbit 2 kali setahun oleh UPT. Pusat Pengembangan

Bahasa (P2B) UIN Mataram. Tersedia online pada

https://journal.uinmataram.ac.id/index.php/cordova

hidup dan pentingnya warna untuk pengumpulan makanan, efek fisiologis dan psikologis warna dan kontribusinya terhadap kesejahteraan manusia, dan pengaruh warna pada perilaku.

\section{Ikonisitas dalam Warna}

Ketika tugas memaknai warna dibuat oleh asosiasi psikologis, hubungan sering didasarkan pada kesamaan, seperti halnya dengan asosiasi jeruk, merah, dan kuning dengan api, matahari, dan panas. Hal ini karena asosiasi semacam ini, dan bukan karena warna akan menyebabkan perbedaan suhu yang nyata, bahwa warna-warna seperti itu ditandai sebagai warna-warna hangat, sementara 'blues' dan 'greenblues'dianggap sebagai warna dingin. Dalam kasus ini, warna berfungsi sebagai tanda ikon.

Indexisitas dalam Warna

Fakta yang diketahui bahwa warna tidak dalam materi fisik, atau dalam radiasi cahaya; ia adalah sebuah gambar yang diproduksi di dalam pikiran suatu organisme yang dilengkapi dengan suatu sistem indera, penglihatan, yang bereaksi terhadap bagian tertentu dari radiasi itu. Gambar atau tanda ini adalah reproduksi yang dibuat oleh sistem visual dari radiasi yang berasal dari sumber cahaya atau dari objek yang memantulkan atau memancarkan radiasi itu. Warna berfungsi sebagai pengganti radiasi fisik yang dibawa ke otak dan memberikan informasi yang berguna tentang dunia luar. Dan, dalam pengertian ini, ia berfungsi sebagai indeks. Sangat jelas bahwa antara citra sensorik, warna tanda, dan fisik, fenomena, radiasi, tidak ada kesamaan atau homologi apa pun, tetapi hanya koneksi fisik, respons neuro-fisiologis, 
Cordova Jurnal

ISSN (P) 2302-3155,

(e) 2714-5808

Vol. 9, No. 12019
Jurnal kajian Bahasa dan Budaya terbit 2 kali setahun oleh UPT. Pusat Pengembangan

Bahasa (P2B) UIN Mataram. Tersedia online pada

https://journal.uinmataram.ac.id/index.php/cordova

yang dibangun selama jutaan tahun selama proses evolusi sistem penglihatan. Indeks adalah sejenis tanda yang berfungsi karena di antaranya dan apa yang diwakilinya terdapat hubungan fisik yang sebenarnya yang terjadi dalam waktu dan ruang tertentu. Karena ini, karakteristik indeks adalah kedekatan antara tanda dan objek. Sebagai contoh, fakta bahwa warna kekuningan dari kulit seseorang diasosiasikan sebagai tanda penyakit yang dibentuk oleh koneksi indeksikal, ia adalah penyakit itu sendiri yang telah menghasilkan pigmentasi kulit.

e. Simbolisitas dalam Warna

Simbol adalah tanda yang memiliki hubungan khusus dengan objek yang ditunjukkannya. Simbol mendefinisikannya secara universal, sedangkan namanya mengacu pada hal-hal khusus. Pemaknaan warna biasanya bersifat independen dari objek di mana warna terlihat. Misalnya, asosiasi hijau = keselamatan, pergi, $\mathrm{kuning}=$ peringatan, hatihati, merah = bahaya, berhenti, diterapkan dalam beberapa situasi selain lampu lalu lintas dan rambu lalu lintas. Dalam konteks pertandingan sepak bola, di beberapa negara, kartu kuning berarti peringatan (peringatan, hati-hati), sementara kartu merah berarti "berhenti bermain, keluar dari pertandingan."

Analisis berikut ini adalah pemaknaan konotasi warna antara masyarakat barat (English speaking country) dan masyarakat Sasak, Lombok Nusa Tenggara Barat. Berikut penulis paparkan persamaan maupun perbedaan pemaknaan konotatif warna pada kedua masyarakat tersebut; 
Cordova Jurnal

ISSN (P) 2302-3155,

(e) 2714-5808

Vol. 9, No. 12019
Jurnal kajian Bahasa dan Budaya terbit 2 kali setahun oleh UPT. Pusat Pengembangan

Bahasa (P2B) UIN Mataram. Tersedia online pada

https://journal.uinmataram.ac.id/index.php/cordova

a. Black Vs Bideng

Warna hitam (black) menurut orang Barat dapat dipersepsikan positif dan negatif. Ia juga bersifat menyampaikan kabar suka cita serta duka cita. Bilamana warna hitam dikatakan memiliki muatan positif? Hitam dipandang positif dalam beberapa frase misalnya 'black tie' untuk menyiratkan sebuah pertemuan sosial yang bersifat formal. Demikian juga dengan frase 'Black little dress', ungkapan ini memiiliki muatan positif untuk menyanjung kefungsian dan elastisitas gaun yang bisa dipakai kapan saja. Demikian juga warna hitam sering dipakai oleh para pendeta utkuk melambangkan kesalihan dan ketaaan terhadap ajaran mereka. Kedua, warna hitam juga dipersepsikan memiliki unsur negative, hitam dikonotasiskan sebagai pembawa kesuraman, kesedihan, dll, hal ini karena hitam identic dengan ketiadaan terang dalam dirinya. seringkali orang Inggris mengungkapkan frase 'Black day', 'black dog', dan juga 'black mood' untuk mengungkapkan perasaan atau suasana hatinya yang sedang tidak baik. 'Black Death' adakah frase yang pernah pupuler di Eropa yang menggambarkan tentang kematian masal akibat penyakit pes yang saat itu melanda daratan Eropa. 'Black look' dalam persepsi orang barat juga memiliki makna negative. Ia bermakna jahat, kelihatan ingin memeras, marah, dan hal-hal buruk lainnya. Hitam juga sering digunakan oleh masyarakat barat untuk menandai sebuah kejadian yang buruk yang berlangsung diwaktu-waktu tertentu misalnya frase 'Black september' adalah kejadian yang berlangsung ketika kelompok paramiliter Arab Palestina menyerang pasukan komando Palestina. Lain yang 
Cordova Jurnal

ISSN (P) 2302-3155,

(e) 2714-5808

Vol. 9, No. 12019
Jurnal kajian Bahasa dan Budaya terbit 2 kali setahun oleh UPT. Pusat Pengembangan

Bahasa (P2B) UIN Mataram. Tersedia online pada

https://journal.uinmataram.ac.id/index.php/cordova

berlangsung pada bulan September tahun 1970. Dan masih banyak ungkapan atau frase yang digunakan untuk menandai muatan negative ketika menggunakan warna hitam, diantaranya adalah black widow, black guard, black eyes, black sheep, black legs dan lain sebagainya. Menyangkut warna yang dikaitkan dengan ras manusia, orang Inggris menganggap bahwa hitam atau manusia kulit hitam identik dengan perbudakan atau kolonialisme, negara terbelakang, masa depan suram, serta menjijikkan. Walaupun sudah modern namun pandangan ini kayaknya tetap berlaku sampai sekarang.

Pada masyarakat Sasak, warna hitam diasosiasikan dengan kesuraman, hal-hal yang menakutkan, dan jahat. Warna hitam juga diasosiasikan sama dengan masyarakat barat yakni menandakan ketiadaan terang misalnya suku Sasak sering mengatakan frase 'batu bideng', 'dedare bideng', 'kelambe bideng' dst. Pemakaian warna 'bideng' dalam masyarakat sasak dominan dipakai dan lebih bersifat orthophemis, namun ada beberapa frase juga walaupun tidak terlalu banyak namun ia mengungkapkan euphimisme, dan disfemisme. Sebagai contoh ungkapan yang bersifat euphimisme adalah 'ate bideng' sebagai penggambaran seseorang yang memiliki hati yang tidak bersih atau suka berbuat jahat terhadap orang lain. Walaupun ada sisi-sisi pemaknaan nagatif terhadap warna hitam, namun dalam tradisi Sasak, warna hitam adalah merupakan symbol warna tertinggi dalam masyarakatnya. Mayoritas masyarakat Sasak dalam acara adatnya selalu menggunakan warna hitam atau gelap sebagai corak Baju adatnya. Masyarakat Sasak khususnya pria memiliki baju adat yang dinamakan 
Cordova Jurnal

ISSN (P) 2302-3155,

(e) 2714-5808

Vol. 9, No. 12019
Jurnal kajian Bahasa dan Budaya terbit 2 kali setahun oleh UPT. Pusat Pengembangan

Bahasa (P2B) UIN Mataram. Tersedia online pada

https://journal.uinmataram.ac.id/index.php/cordova

'Godek Nungkik'. Baju adat ini identik dengan warna hitam. Menurut persepsi masyarakat Sasak, warna hitam atau gelap, adalah perlambang kedamaian, perlambang persaudaraan, rendah hati, jujur, apa adanya. Warna hitam juga melambangkan keterbukaan. Menyangkut penggambaran warna hitam dalam penilaian ras manusia, suku Sasak tidak memiliki pemaknaan yang bersifat 'deskriminatif' tidak ada yang lebih dan kurang antar warna kulit. Ini kemungkina terkait dengan sifat Suku Sasak yang terbuka, toleran serta tidak pernah mengalami pasang surut tragedi kemanusiaan, kolonialisme terkait dengan warna kulit seperti yang terjadi pada masyarakat barat.

b. White vs Putik

Di antara Anglos, warna putih diasosiasikan dengan kemurnian dan cahaya, kebebasan dari niat jahat, bersifat dermawan, yang tidak bersalah, yang tidak berbahaya. Biasanya orang barat sering mengkontaskannya dengan warna hitam misalnya Ksatria Putih yang baik (dalam baju besi bersinar) versus Ksatria Hitam dan fakta bahwa penjahat secara tradisional mengenakan pakaian hitam di film-film Hollywood. Di Roma Kuno, ada tanda-tanda kemenangan dan hari-hari yang menguntungkan ditandai pada kalender dengan kapur putih. Sihir putih itu bagus, ilmu hitam itu buruk. Pekerja kerah putih secara sosial lebih unggul dari pekerja kerah biru. Pengantin modern memakai warna putih sebagai simbol kesucian dan kemurnian (bahkan jika dia tidak lagi perawan). Anglos berkulit putih dan, seperti yang sudah dikatakan, sampai abad ke-20, kulit putih yang kulitnya seperti terbakar matahari 
Cordova Jurnal

ISSN (P) 2302-3155,

(e) 2714-5808

Vol. 9, No. 12019
Jurnal kajian Bahasa dan Budaya terbit 2 kali setahun oleh UPT. Pusat Pengembangan

Bahasa (P2B) UIN Mataram. Tersedia online pada

https://journal.uinmataram.ac.id/index.php/cordova

dipandang rendah daripada bangsawan halus dan pucat. Jadi untuk menjadi putih adalah pujian dan atribusi warna gelap adalah dysphemistic. Berbeda dengan hitam, putih jarang digunakan secara dysphemistikal.

Warna putih (putik) dalam masyarakat suku Sasak diasosiasikan dengan ketulusan, kedermawanan, kebaikan. Warna putih juga dimaknai sebagai lambang kesolehan. Sebagai masyarakat yang mayoritas masyarakatnya menganut agama Islam, dalam ritual keagamaannya, warna putih adalah warna baju dominan yang dipakai didalam pelaksanaanya. Di samping itu, warna putih juga dijadikan sebagai lambang 'kematian'. Pada masyarakat sasak, pada prosesi kematian, dari awal kematian sampai proses penguburan, kebanyakan prosesinya identik dengan warna putih. Pada saat orang melayat ke rumah duka, biasanya 'bendera putih' atau 'kain putih' di taruh didepan rumah orang yang meninggal atau dipinggir jalan didekat rumah orang yang meninggal untuk mengabarkan bahwa kepada khalayak bahwa ada peristiwa kematian yang terjadi di lingkungan tersebut. Demikian juga pada proses memandikan jenazah, baju yang dipakai si mayit, serta kelambu yang dipakai untuk menutup proses pemandiannya didominasi oleh warna putih. Demikian sampai ia masuk liang lahat, dikafani oleh kain berwarna putih. Sama seperti warna hitam, kebanyakan warna ini bersifat orthophemis, dan jarang dipakai sebagai euphimis, serta disfemis.

c. Gray Vs Abu-abu 
Cordova Jurnal

ISSN (P) 2302-3155,

(e) 2714-5808

Vol. 9, No. 12019
Jurnal kajian Bahasa dan Budaya terbit 2 kali setahun oleh UPT. Pusat Pengembangan

Bahasa (P2B) UIN Mataram. Tersedia online pada

https://journal.uinmataram.ac.id/index.php/cordova

'Gray Nomads' di Australia adalah pensiunan yang melakukan perjalanan di seluruh negeri; frasa itu bersifat ortofemistik. Begitu juga, 'Gray Power' adalah kekuatan dari kelompok lobi untuk warga 'senior' di Australia dan Selandia Baru dan frasa ini mengakui kekuatan politik yang berpotensi kuat di AS dan Eropa sebagai usia populasi. Ada juga istilah atau frase 'Gray Panthers' yang mengkampanyekan partisipasi aktif masyarakat oleh orang-orang dari segala usia untuk pembentukan pendidikan umum seumur hidup, sistem perawatan kesehatan universal, program jaminan sosial yang lebih kuat, hak-hak pekerja, pelestarian lingkungan, keamanan melalui kedamaian bukan perang, dan isu-isu serupa tentang kepedulian sosial dan kemanusiaan. Abu-abu bersifat dysphemistik menggambarkan cuaca membosankan, negara suram dan orang-orang membosankan. Dan di antara orang Afrika 'Gray America' adalah disfemisme untuk kulit putih.

Pada masyarakat suku Sasak, warna abu sangat jarang dipakai. Ia hampir tidak memiliki pemaknaan konotatif terkait dengan warna ini. Bahkan 'abu-abu' yang banyak dipakai sebagai perlambang orang yang memihak diantara dua hal, tidak diadopsi oleh masyarakat Sasak. Masyarakat Sasak bahkan cenderung menggunakan frase 'belang ate' atau yang memiliki hati belang-belang untuk menggambarkan orang yang memiliki dualism preferensi atau dualisme dukungan.

d. Brown vs Coklat

Warna ini diasosiasikan positif untuk zat berwarna coklat tertentu seperti roti coklat, beras merah, dan gula merah - semua orthophemisms (kecuali untuk penggunaan eufemisme gula coklat untuk " heroin ", 
Cordova Jurnal

ISSN (P) 2302-3155,

(e) 2714-5808

Vol. 9, No. 12019
Jurnal kajian Bahasa dan Budaya terbit 2 kali setahun oleh UPT. Pusat Pengembangan

Bahasa (P2B) UIN Mataram. Tersedia online pada

https://journal.uinmataram.ac.id/index.php/cordova

warna coklat sering dikaitkan dengan disfemisme dan disfisme eufimistik. Ada juga sisi negative dari warna cokelat yakni ketika pada abad ke-20, kulit putih yang terbakar matahari seperti coklat seperti buah beri diremehkan karena, mereka identik dengan pekerja rendahan yang bekerja di luar ruangan. Menyimpulkan, warna coklat adalah dysphemistic ketika dikaitkan dengan faeces atau polusi lainnya sama seperti ketika menyebut 'Brownfield site' untuk menyebut warna daerah yang terkena dampak polusi dan terpapar kimia.

Warna ini hampir sama dengan warna abu-abu, ia sangat-sangat jarang dipakai oleh masyarakat Sasak terkait dengan pemaknaan konotatif yang bersifat orthopemis, euphemis, maupun disfemis. Warna ini tidak terlalu berkesan. Bahkan warna ini tidak memiliki makna konotatif sama sekali.

e. Yellow Vs Kuning

Kuning hampir selalu ortofemis tetapi kadang-kadang disfemistik. Seperti hijau, itu diterapkan pada orang-orang yang takut atau cemburu. Masih sangat aktif disfemistik dan menghina adalah ketika memanggil seseorang dengan panggilan 'Yellow atau Yellow Bellied' karena konotasi dari frase tersebut adalah "pengecut dan penakut'. Seperti putih, hitam dan coklat, kuning digunakan untuk warna kulit. Ungkapan bahaya kuning adalah disfemisme rasis yang mengacu pada bahaya yang diperkirakan bahwa orang-orang Asia akan membanjiri orang kulit putih. Di antara orang Afrika Amerika, orang kuning (yaller) adalah orang coklat muda dan julukannya sopan. Kulit 
Cordova Jurnal

ISSN (P) 2302-3155,

(e) 2714-5808

Vol. 9, No. 12019
Jurnal kajian Bahasa dan Budaya terbit 2 kali setahun oleh UPT. Pusat Pengembangan

Bahasa (P2B) UIN Mataram. Tersedia online pada

https://journal.uinmataram.ac.id/index.php/cordova

kuning menurut persepsi orang barat memiliki posisi di atas orang dengan kulit coklat dan kulit ciklat di atas kulit hitam.

Warna kuning diasosiasikan masyarakat sasak sebagai warna perlambang keindahan, kecantikan. Biasanya untuk menyatakan seseorang itu sangat cantik, masyarakat sasak akan mengatakan "Dedare tie putik kuning'. Namun warna ini harus dipadukan dengan warna putih 'putik kuning'. Warna putih juga dipakai namun jika dirangkai dengan warna kuning, maka ia akan memiliki derajat pemaknaan yang lebih tinggi terhadap kata cantik itu sendiri. Dalam nuansa politik, masyarakat Sasak akan menjeneralisir bahwa warna ini identic dengan salah satu partai yakni 'Partai Golkar' walaupun mungkin ada partai lainnya yang memiliki warna kuning yang sama. Warna kuning juga diidentikkan sebagai sesatu yang menjijikkan. Ia adalah perlambang kotoran manusia. Berbeda dengan masyarakat barat yang memposisikan warna cokelat sebagai perlambang kotoran manusia, orang Sasak menggunakan warna kuning sebagai prlambang kotoran manusia.

f. Red Vs Beak

Warna merah, adalah warna yang paling menonjol diantara semua warna dan paling banyak digunakan. Warna merah telah digunakan oleh sistem kontrol lalu lintas di tanda-tanda berhenti dan lampu lalu lintas. Merah adalah warna keberuntungan bagi budaya Cina. Warna merah juga digunakan untuk menandai hal-hal sebagai berikut: 'Red Carpet' adalah istilah untuk karpet yang dibentangkan untuk dilalui khusus untuk orang yang masuk dalam kategori VIP. 'Red Alert' adalah penanda untuk menunjukkan peringatan tentang sesuatu 
Cordova Jurnal

ISSN (P) 2302-3155,

(e) 2714-5808

Vol. 9, No. 12019
Jurnal kajian Bahasa dan Budaya terbit 2 kali setahun oleh UPT. Pusat Pengembangan

Bahasa (P2B) UIN Mataram. Tersedia online pada

https://journal.uinmataram.ac.id/index.php/cordova

yang bersifat berbahaya. Warna merah juga dipersepsikan sebagai lambang kejantanan di frase 'Red-hot' dan 'Red Bloodies Male'. Namun merah memiliki lebih banyak disfemistik daripada asosiasi eufemisme untuk bahasa Inggris. Orang-orang Indian merah mungkin mendapat julukan dari dua sumber: satu untuk mencemari mereka dari Indian India (coklat atau hitam); yang lain dari cat oker merah yang dikenakan oleh beberapa penduduk asli Amerika dan penduduk asli Kanada dalam upacara dan perang. Karena sikap negatif terhadap penduduk asli Amerika, stereotip dalam Barat, istilah Indian Merah hampir ditinggalkan sebagai disfemistik. Jadi, secara keseluruhan, konotasi warna merah mencerminkan aspek positif dan negatif dari darah kehidupan kita.

Pada masyarakat Sasak, warna merah diasosiasikan sebagai lambang keberanian, keangkuhan, amarah, kejantanan. Warna merah lebih bersifat disfemis dan juga diasosiasikan sebagai eufimis, walaupun jumlahnya dalam relative kecil. 'kanak beak' dalam masyarakat sasak bermakna seseorang yang tidak professional, masih harus banyak belajar, dan kurang berpengalaman.

g. Green Vs Ijo

Hijau, pelengkap warna merah, dikatakan sebagai warna yang tenang. Menjadi warna dominan daun yang hidup. Green belt, greenways, green wedges mengacu pada blok yang sebagian besar belum berkembang, liar, atau lahan pertanian yang berdekatan dengan daerah perkotaan. Gaun hijau (Green Gown) adalah eufemisme untuk hilangnya keperawanan. Orang kulit putih kadang-kadang dikatakan 
Cordova Jurnal

ISSN (P) 2302-3155,

(e) 2714-5808

Vol. 9, No. 12019
Jurnal kajian Bahasa dan Budaya terbit 2 kali setahun oleh UPT. Pusat Pengembangan

Bahasa (P2B) UIN Mataram. Tersedia online pada

https://journal.uinmataram.ac.id/index.php/cordova

berubah menjadi hijau (Turn Green) karena sakit hati, takut, marah atau iri hati. Buah mentah seperti apel, pir, dan peach biasanya berwarna hijau dan tidak enak; karakteristik ini telah ditransfer dan diperluas pada orang-orang dan hal-hal lain secara dysphemistically dikatakan hijau jika mereka belum dewasa, tidak berpengalaman, belum berkembang, belum matang, mentah. Jadi, penggunaan metafora hijau secara dominan disfemistik.

Warna hijau (ijo) diasosiasikan sebagai lambang kesuburan, derajat kesalihan tinggi. Para ulama yang beraliran sufi atau yang mendalami tarekat, sering menggunakan warna ini sebagai surban dalam berdakwah. Warna hijau diyakini memiliki nilai mistifikasi yang lebih tinggi dibandingkan dengan warna putih meskipun warna ini juga memiliki konotasi kesalihan. Dalam pergaulan dan percakapan seharihari, warna hijau lebih banyak bersifat atau diasosiasikan eufimis. Frase 'masih ijo', 'kanak ijo' memiliki pemaknaan bahwa seseorang itu masih belum professional, atau belum banyak memiliki kelebihan atau keterampilan tertentu, hampir sama dengan 'kanak beak' untuk warna merah.

h. Blue Vs Biru

Warna biru sebagian besar digunakan secara orthophemistik, meskipun ada beberapa penggunaan figuratif yang mendekati eufemisme seperti darah biru untuk keluarga aristokrat. Pemakaian warna biru menandakan kebajikan. Kebiasaan ini terinspirasi oleh pakaian biru yang dikenakan oleh Madonna di sebagian besar lukisannya. Sebelum akhir abad ke-19, warna biru adalah warna yang 
Cordova Jurnal

ISSN (P) 2302-3155,

(e) 2714-5808

Vol. 9, No. 12019
Jurnal kajian Bahasa dan Budaya terbit 2 kali setahun oleh UPT. Pusat Pengembangan

Bahasa (P2B) UIN Mataram. Tersedia online pada

https://journal.uinmataram.ac.id/index.php/cordova

populer untuk gaun pernikahan, dan gadis-gadis sering kali berpakaian biru. Merah muda untuk anak perempuan dan biru untuk anak laki-laki adalah kebiasaan yang berkembang setelah tahun 1930-an. Atribut biru berarti 'orang baik, kuat, dapat diandalkan; seorang penganut setia " (nasionalisme di Inggris dan Australia kadang-kadang digambarkan sebagai biru sejati). Sekutu untuk penggunaan tersebut adalah pita biru " sangat bagus ", pita biru terkait " terbaik di kelas (dari usaha olahraga). Di sisi lain, pekerja kerah biru, juga dinamai secara metonim untuk warna seragam mereka, merujuk secara ortofemik kepada pekerja manual atau industri. Sebagai genre musik, blues sering memiliki lirik putus asa; misalnya Blind's Lonesome Christmas Blues.

Warna ini, sama seperti di barat, pada masyarakat suku Sasak ia banyak digunakan secara orthophemistik. Sangat jarang dipakai secara, eufimis dan disfemis. Hanya 'darak biru' yang mendekati makna eufimis. Penulis mensinyalir bahwa frase inipun adalah serapan dari bahasa asing atau bahasa Indonesia. Sementara untuk pemaknaan makna konotasi lainnya, sangat langka bahkan mungkin tidak ada sama sekali kita menemukan frase yang diasosiasikan dengan warna ini.

i. Metalic Vs. Nyeleng

Emas adalah logam estetis yang sangat menarik. Istilah emas banyak digunakan dalam evaluasi positif seperti masa keemasandan pujian seperti anak emas, dia bagus seperti emas, dia sangat berharga dalam emas, dia memiliki hati emas. Mungkin satu-satunya disfemisme emas adalah di mana seorang wanita digambarkan sebagai penggali emas (Gold digger) ketika dia dikritik karena menempelkan dirinya 
Cordova Jurnal

ISSN (P) 2302-3155,

(e) 2714-5808

Vol. 9, No. 12019
Jurnal kajian Bahasa dan Budaya terbit 2 kali setahun oleh UPT. Pusat Pengembangan

Bahasa (P2B) UIN Mataram. Tersedia online pada

https://journal.uinmataram.ac.id/index.php/cordova

pada seorang pria hanya untuk keuntungan finansial. Nilai X-phemistic dari warna metalik berasal dari karakteristik mereka sebagai logam daripada dari warna khas mereka

Sama seperti di masyarakat barat, warna emas 'nyeleng' identik dengan kemewahan, keagungan, dan kesayangan. Terkait dengan warna inipun, dalam masyarakat Sasak kitapun akan menemukan sedikit frase yang digunakan secara eufimis. Bahkan untuk disfemis, kita tidak akan menemukannya sama sekali. 'Anak emas' dalam masyarakat Sasak bermakna anak yang paling disayang atau kesayangan seseorang-bisa orang tua, guru dll. 'Nyeleng mate', frase ini bukannya menggambarkan bahwa seseorang memiliki pengliatan yang bagus, tetapi ia bermakna masih junior, masih sangat kecil, belum memiliki pengalaman apa-apa. Tingkatannya masih dibawah 'masih ijo', 'kanak beak' baru kemudian 'nyeleng mate'.

\section{KESIMPULAN}

Berdasarkan analisis dan pembahasan diatas, dapat disimpulkan beberapa hal; bahwa secara kuantitas, pemaknaan secara orthopemis, eufimis, serta disfemis masyarakat barat lebih kaya dibandingkan dengan pemaknaan yang ada pada masyarakat Sasak. Makna orthopemik, eufimis, dan disfemis pada masyarakat Sasak hanya dapat ditemukan pada warna primer. Sementara warna sekunder (warna yang berasal dari percampuran warna lain), hampir jarang diteemukan pemaknaan konotasi yang bersifat eufimis, dan disfemis. Kalaupun ada, 
Cordova Jurnal

ISSN (P) 2302-3155,

(e) 2714-5808

Vol. 9, No. 12019
Jurnal kajian Bahasa dan Budaya terbit 2 kali setahun oleh UPT. Pusat Pengembangan

Bahasa (P2B) UIN Mataram. Tersedia online pada

https://journal.uinmataram.ac.id/index.php/cordova

itupun dikarenakan masyarakat Sasak mengambil atau meminjam istilah atau frase tersebut dari bahasa lain, dalam hal ini dapat terlihat pada frase 'darak biru'. Kekayaan pemaknaan konotatif warna pada masyarakat disebabkan karena proses semiosisnya dipengaruhi oleh cara pandang, kekayaan budaya, pengalaman, kejadian yang beragam yang terjadi pada masyarakat barat. Sementara itu, pada masyarakat Sasak, proses semiosisnya cendrung minim akibat kurangnya interaksi, pengalaman, pengalaman sejarah, serta minimnya metaphor bahasa. 
Cordova Jurnal

ISSN (P) 2302-3155,

(e) 2714-5808

Vol. 9, No. 12019
Jurnal kajian Bahasa dan Budaya terbit 2 kali setahun oleh UPT. Pusat Pengembangan

Bahasa (P2B) UIN Mataram. Tersedia online pada

https://journal.uinmataram.ac.id/index.php/cordova

\section{Daftar Pustaka}

Barthes, Roland. 1957. Mythologies. Paris: Editions de Suil.

Barthes, Roland. 1968. Elements of Semiology. New York: Hill and Wang.

C. Jannello, Fondements pour une semiotique cientifique de la conformation delimitante des objets du monde naturel, in Semiotic Theory and Practice, Proceedings of the 3rd Congress of the International Association for Semiotic Studies, M. Herzfeld and L. Melazzo, Eds., Mouton de Gruyter, Berlin, 1988, vol. I, pp. 483-496.

C. Morris, (1938) Foundations of the theory of signs, in International Encyclopedia of Unified Science Vol. 1, No. 2, O. Neurath, Ed., The University of Chicago Press, Chicago.

Caivano, Hose Luis (1998). Color and Semiotics: A Two-way Street. New York: John Wiley and Sons, Inc.

Hasyim, Muhammad Hasyim. 2014. Konstruksi Mitos dan Ideologi dalam Iklan Komersial Televisi, Suatu Analisis Semiologi. Disertasi. Makassar: Universitas Hasanuddin

Muhammad Hasyim (2015). Konotasi 'Green Business dan Green Technology' paper yang dibawakan dalam International Conference on Language, Society and Culture (ICLCS) di Jakarta.

Muhammad Hasyim (2017). Metafora Konsumerisme, dalam Journal of Language Teaching and Research. Vol. 8, No. 3 (523-530). 
Cordova Jurnal

ISSN (P) 2302-3155,

(e) 2714-5808

Vol. 9, No. 12019
Jurnal kajian Bahasa dan Budaya terbit 2 kali setahun oleh UPT. Pusat Pengembangan

Bahasa (P2B) UIN Mataram. Tersedia online pada

https://journal.uinmataram.ac.id/index.php/cordova

Peirce, Charle Sander. 1966. Philosophical Writings of Peirce. (Justus Buchler., Ed.) New York: Dover Publications.

Saussure, Ferdinand de. 1967. Cours de Linguistique Générale. Paris: Payot 